\title{
Quand le rite devient technique. Sacrifice et abattage rituel dans le monde musulman
}

Pierre Bonte

\section{(2) OpenEdition \\ 12 Journals}

Édition électronique

URL : https://journals.openedition.org/tc/608

DOI : $10.4000 /$ tc. 608

ISSN : 1952-420X

Éditeur

Éditions de l'EHESS

\section{Édition imprimée}

Date de publication : 1 septembre 1994

ISSN : 0248-6016

\section{Référence électronique}

Pierre Bonte, «Quand le rite devient technique. Sacrifice et abattage rituel dans le monde musulman », Techniques \& Culture [En ligne], 21 | 1994, mis en ligne le 30 décembre 2005, consulté le 29 septembre 2022. URL : http://journals.openedition.org/tc/608; DOI : https://doi.org/10.4000/tc.608

Ce document a été généré automatiquement le 29 septembre 2022.

Tous droits réservés 


\section{Quand le rite devient technique. Sacrifice et abattage rituel dans le monde musulman}

Pierre Bonte 